\title{
REFLECTION OF THE REQUIREMENTS OF
} THE APPLICATION OF ELECTRONIC MANAGEMENT IN IMPROVING JOB

\section{PERFORMANCE - FIELD RESEARCH IN THE DIRECTORATE OF HILLA MUNICIPALITY}

\author{
Dr. Walaa Ismail Abdul Latif, Research : Hussein JaafarJawad \\ College of Administration and Economics \\ University of Baghdad
}

DOI: $10.37648 / \mathrm{ijrssh.v10i03.013}$

Received: $05^{\text {th }}$ June, 2020; Accepted:28 ${ }^{\text {th }}$ June, 2020; Published: $01^{\text {st }}$ July,2020

\begin{abstract}
The research aims to measure the reality of the two variables of the electronic administration research in improving job performance in the directorate of Hilla municipality, as the importance of the research comes from the importance of its researched variables as it is an important topic in administrative thought, and the research has been applied in the directorate of Hilla, and the researcher has adopted the descriptive analytical approach in his achievement For research, as the research included an answer to the questions related to the research problem that relate to the fact that most Iraqi organizations, especially public sector organizations, do not rely on the application of the principles of electronic management, and by testing a number of sub-major assumptions with regard to relationship and influence relationships, the research sample was represented by (102) (Employee from the total number of employees in the directorate, and the questionnaire was used to collect information and data on the practical side, as the questionnaires were distributed to the said sample, and the recovery rate was (102), i.e. (100\%) and the statistical methods represented in (iterations Arithmetic mean - weighted arithmetic mean - standard deviation - coefficient of variation), and the data was processed through the SPSS program, and the research reached a set of results, most notably that management She has a tendency to adopt serious and non-stereotypical ideas regarding the topics of employing computer technologies and programs to facilitate work for the employee first and the citizen second, either of the most important recommendations for the Directorate to provide rewards and incentives to employees who complete their work properly to raise their spirits and urge them to do their best.
\end{abstract}

Key words: electronic management, electronic management requirements, job performance.

\section{INTRODUCTION}

The world is witnessing significant development and progress recently, which calls for services, whether profit or service, to keep pace with these developments. In order to achieve advanced levels of performance, it had to be part of the global development movement, by employing modern technology in the management of the 
organization, Accordingly, organizations have started to develop their tools in line with the requirements of the current era, by changing their tools from traditional to electronic by adopting electronic management, which in turn affects job performance significantly.

Electronic management in government organizations, especially service ones, contributes significantly to achieving more coherence in completing transactions and performing various functions in a manner that creates more participation and an increase in credibility in providing services fairly and in accordance with the laws, in addition, it represents an integrated approach to investing good time and promoting Quality of service to achieve citizen satisfaction and increase the efficiency of job performance.

The global transformation has led to the economic system, due to which the interest in electronic management has increased in many organizations in recent years. The success of the organizations in providing the best possible service is due to its reliance on modern technological information systems in managing its own database in a way that facilitates the process of managing administrative and service operations.

\section{THE FIRST AXIS: RESEARCH METHODOLOGY AND PREVIOUS STUDIES}

\section{First: research methodology \\ 1- Research problem}

Service organizations today in order to keep pace with rapid technological developments and to preserve their standing and reputation need to adopt modern methods of management, because the old methods are not meeting the aspirations of societies as they are characterized by complexity, routine and bureaucracy, and from those methods of electronic management, it was noted that electronic management is limited through The old rules and procedures applied, as the researched organization depends in the completion of its transactions on the traditional methods and the associated waste in time and effort, in addition to that it cannot adapt to the data of its internal environment and changes in the external environment, which is represented by technological and digital development and the extent of this impact on job performance In general, and accordingly, the problem can be formulated by raising the following questions:

1- To what extent does the Hilla Municipality directorate understand the concepts, mechanisms and requirements of implementing electronic management?

2- Is there a correlation and impact between electronic management and job performance?

3- Is the cadre in the Directorate of Hilla Municipality ready to activate the role of electronic management in the researched organization?

\section{2- research importance}

The importance of research is embodied in the importance of the researched variables (electronic management, job performance), as electronic management is one of the contemporary issues that are closely related to performance, as organizations that adopt methods of electronic management can achieve high levels of performance because they have got rid of the traditional methods, waste and waste In the effort and time, in addition to the awareness of the importance of electronic management leads to achieving a large amount of transparency, justice, credibility and efficient use of the organization's resources, whether human or material, all of these elements lead to achieving the best levels of job performance compared to organizations that still adopt traditional methods and conduct their paperwork in a manner routine.

\section{3- research aims}

The researchers seek, through their research, to achieve goals that are compatible with modern concerns of organizations, in order to lay down modern scientific and administrative foundations for managing organizations, so the goals of the research are as follows:

1- Highlighting the correlation and influence between electronic management and job performance.

2- Clarify the concept of job performance, its importance and the most important factors affecting it. 
3- Clarifying the role that electronic management plays in enhancing and raising levels of job performance in the Hilla Municipality directorate.
4- Reaching results and submitting recommendations to the Municipality of Hilla, which can help in finding solutions to the obstacles to implementing electronic management.

\section{4- Research hypothesis}

A hypothetical diagram is an intellectual construction of a set of facts that provide a simplified, brief and hypothetical conception of the phenomena under study. The hypothetical scheme of research can be clarified as follows:

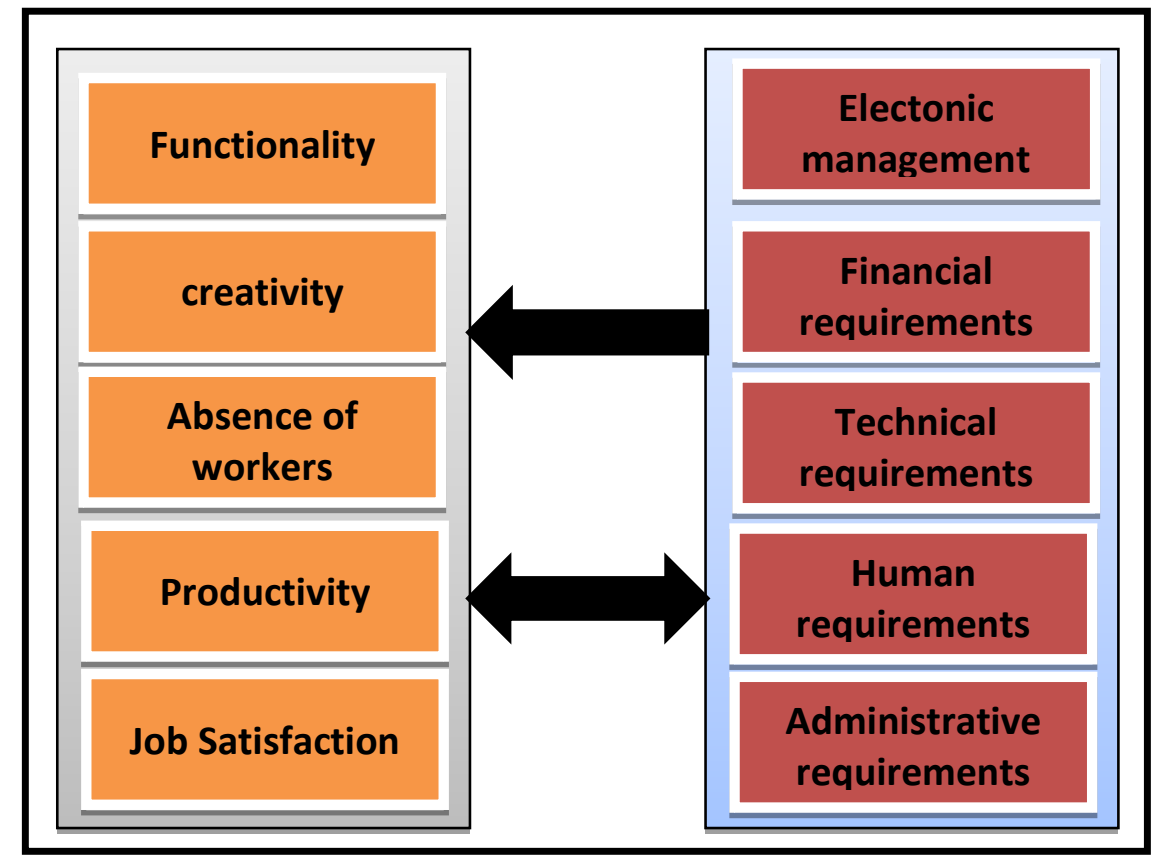

Source: Prepared by the two researchers

Figure (1) schematic of the hypothesis of the research

\section{5- research assumes}

The current research hypotheses are formulated according to the research problem, its objectives and the hypothetical scheme, as the hypotheses attempt to answer the questions mentioned in the problem, through testing all the hypotheses statistically, and the research hypotheses can be clarified as follows:

The first main hypothesis: There is a significant correlation between electronic management and job performance, and the following sub-assumptions are derived from it:

The first sub hypothesis: There is a significant correlation between administrative requirements and job performance.
The second sub-hypothesis: There is a significant correlation between human requirements and job performance.

The third sub-hypothesis: There is a significant correlation between technical requirements and job performance.

Fourth hypothesis: There is a significant correlation between financial requirements and job performance.

The second main hypothesis: There is a significant effect between electronic management and job performance, and the following sub-assumptions are derived from it: 
The first sub-hypothesis: There is a significant effect between administrative requirements and job performance.

The second sub-hypothesis: There is a significant effect between human requirements and job performance.

The third sub-hypothesis: There is a significant effect between technical requirements and job performance.

Fourth hypothesis: There is a significant effect between financial requirements and job performance.

\section{6- research community}

The research community included the Directorate of Hilla Municipality, including all the administrative levels within the organizational structure, and the questionnaire form was relied upon, as (102) questionnaires were distributed, and they were fully retrieved, i.e. the rate of retrieval was (100\%), so that the researcher is within the formations of one district Workers in it, has been distributed within the levels of upper and middle management within the organizational structure of the directorate, and Table (1) shows the characteristics of the research sample:

\begin{tabular}{|c|c|c|c|c|c|}
\hline $\begin{array}{l}\text { The ratio } \\
\%\end{array}$ & the number & Property distribution & \multicolumn{3}{|c|}{$\begin{array}{l}\text { Personal characteristics of the } \\
\text { research sample }\end{array}$} \\
\hline 93.1 & male & male & \multirow{2}{*}{\multicolumn{2}{|c|}{ Sex }} & \multirow{2}{*}{1} \\
\hline 6.9 & 7 & female & & & \\
\hline$\% 100$ & 102 & Total & & & \\
\hline 2.9 & 3 & 35 One year or less & & \multirow{5}{*}{$\begin{array}{l}\text { Age group } \\
\text { (year( }\end{array}$} & \multirow{5}{*}{2} \\
\hline 14.7 & 15 & less than - 3540 & & & \\
\hline 38.2 & 39 & 40less than 45 - & & & \\
\hline 25.5 & 26 & 45less than50- & & & \\
\hline 18.6 & 19 & 50 One year or more & & & \\
\hline$\% 100$ & 102 & \multicolumn{4}{|l|}{ Total } \\
\hline- & - & Prep & & \multirow{6}{*}{$\begin{array}{l}\text { Educational } \\
\text { attainment }\end{array}$} & \multirow{6}{*}{3} \\
\hline 2.0 & 2 & Technical / Technical Diploma & & & \\
\hline 91.2 & 93 & $\mathbf{B A}$ & & & \\
\hline 1.0 & 1 & \multicolumn{2}{|l|}{ Higher Diploma } & & \\
\hline 3.9 & 4 & \multicolumn{2}{|l|}{ M.A. } & & \\
\hline 2.0 & 2 & \multicolumn{2}{|l|}{ Ph.D. } & & \\
\hline$\% 100$ & 102 & \multicolumn{4}{|l|}{ Total } \\
\hline 7.8 & 8 & \multicolumn{2}{|l|}{ Less than 10 years } & \multirow{5}{*}{$\begin{array}{l}\text { Years of } \\
\text { service }\end{array}$} & \multirow{5}{*}{4} \\
\hline 25.5 & 26 & -10Less than 15 years old & & & \\
\hline 37.3 & 36 & \multicolumn{2}{|l|}{-15Less than 20 years } & & \\
\hline 17.6 & 18 & \multicolumn{2}{|l|}{ - 20Less than 25 years old } & & \\
\hline 11.8 & 12 & \multicolumn{2}{|l|}{ 25years and over } & & \\
\hline$\% 100$ & 102 & \multicolumn{4}{|l|}{ Total } \\
\hline
\end{tabular}

Source: Prepared by the two researchers

It is evident from Table (1) above:

1- The percentage of males was $(93.1 \%)$, with a frequency of (95) of the total research community, while the percentage of females was (6.9\%) and with a frequency of (7) of the total surveyed population, as this ratio indicates an increase in the percentage of males in the Municipality of Hilla compared to females This percentage is very small, which indicates other factors such as social factors and norms that restrict society in the city of Hilla. 
2 - The percentage of the age group that ranges between (40 - less than 45 years) is the highest percentage (38.2\%) of the research community, and iterates (39), and the age group that ranges between (45 - less than 50 years) has followed it repeatedly (26) At a rate of $(25.5 \%)$, while the age group (50 years and over) obtained a percentage of (18.6\%) and by repetition (19), while the age group (35 - less than 40 years) was $(14.7 \%)$ by repetition (15) while the category ( Less than 35 years), I got the lowest rate $(2.9 \%)$ by repeating (3), as the results indicate that the research community owns expertise and knowledge in their field of specialization, as well as their acquisition of these experiences due to the long time period and the career context in the field of expertise from the career side who are descended Of which, which reflected on their administrative and technical maturity and their ability to make decisions.

3- While the highest educational attainment percentage for the research community was for a bachelor's degree with a ratio of $(91.2 \%)$ and with a frequency of (93), while the master's degree category obtained the second order with a rate of $(3.9 \%)$ and with a frequency of (4), while the doctorate and higher diploma category obtained a percentage $(2.0 \%, 1.0 \%)$ and repeat (2) (1), respectively, as for the sample Holders of a technical / technical diploma certificate, their number was (2), i.e. a percentage of $(2.0 \%)$ of the respondent sample, as researchers note that the employees of the Municipality of Hilla are distinguished by having university degrees, and through the above percentages we find that the members of the research sample are those with scientific qualifications Good that should fit into the nature of their jobs. In addition to having the ability to understand and understand the paragraphs of the questionnaire, which will reflect positively on the final results of the study.

4- While the research community was distributed according to the years of service, as the service category that ranges between (15 - less than 20 years) got the highest percentage (37.3\%) and iterated (38), while the service category (10 - less than 15 years) got The rate of (26\%) and by repetition (25.5). As for the service category that ranges between (20 - less than 25 years), their percentage was (17.6\%) and by repetition (18). With regard to the service category (25 years or more), it obtained a percentage of (11.8) \%), I.e. by repetition (12), and finally the service category (less than 10 years) got the lowest percentage (7.8) and by repetition (8), which shows that the sample examined is characterized by intellectual maturity, and skillful integration between all levels, and this creates strength for study, especially in The sample's answer to the paragraphs of the questionnaire, in terms of understanding and understanding.

\section{6-Sources of data collection}

The data and information necessary to reach the research goals were collected through tools that some of them were related to the theoretical side and others related to the practical side and my agencies:

A- The theoretical side has been provided through Arabic and foreign books, research, periodicals, magazines and the Internet.

b- Personal interviews: Personal interviews were used for the purpose of collecting data and information, as it represents one of the effective methods, as it enables the researcher to obtain information directly.

C- The questionnaire: A number of previous studies were examined that dealt with one or more of the research variables and after making adjustments to the questions in a manner appropriate to the research, in order to design the questionnaire for the research in order to obtain the necessary data to support the practical side of the research and based on the fivedegree Likert scale To classify the degrees of the answer, which ranges between (1-5) degrees, which is formed by (completely agree, agree, neutral, do not agree, do not completely agree) respectively. 
Second: Previous studies

1- (Al-Oqabi: 2018) Requirements for the implementation of electronic management of human resources and their role in the performance of the Iraqi General Insurance Company - Applied Research.

\begin{tabular}{|l|l|}
\hline Purpose of the study & $\begin{array}{l}\text { Determine the extent to which electronic management can be applied in a } \\
\text { manner consistent with the Iraqi environment and diagnose the most important } \\
\text { stages and steps that can be followed in the conversion process to keep pace } \\
\text { with technological developments, especially in the areas of information } \\
\text { technology. }\end{array}$ \\
\hline \multirow{2}{*}{ the importance of studying } & $\begin{array}{l}\text { The importance of research is reflected in its relative scarcity in applied } \\
\text { research and studies in the field of electronic management as it is a new and } \\
\text { vital application that has emerged as a result of transformations and } \\
\text { developments witnessed by the world since the transition from traditional work } \\
\text { to the stage of electronic work away from paper transactions. }\end{array}$ \\
\hline Society and study sample & \begin{tabular}{l} 
Iraqi Insurance Company \\
\hline Research Methodology
\end{tabular} \\
\hline Search tool & Analytical descriptive \\
\hline The most important results & $\begin{array}{l}\text { The administrative requirements for implementing electronic administration are } \\
\text { available at the Iraqi General Insurance Company. }\end{array}$ \\
\hline $\begin{array}{l}\text { The } \\
\text { recommendations }\end{array}$ & $\begin{array}{l}\text { Attention to support and provide a security system to protect workers in the } \\
\text { company and work on all electronic transactions. }\end{array}$ \\
\hline
\end{tabular}

2- (Shaaban: 2018) Reflection of the quality of work life on job performance - an exploratory study of the opinions of a sample of workers in the municipality of Baquba.

\begin{tabular}{|l|l|}
\hline Purpose of the study & $\begin{array}{l}\text { Identify the effect of the dimensions of the quality of work life combined on the } \\
\text { level of job performance of workers in the municipality of Baquba. }\end{array}$ \\
\hline the importance of studying & $\begin{array}{l}\text { This topic helps in identifying the best methods and strategies that service } \\
\text { organizations can rely on in applying the concept of quality of work life, and } \\
\text { then improving the performance of their workers. }\end{array}$ \\
\hline Society and study sample & Baquba Municipality Directorate. \\
\hline Research Methodology & Analytical descriptive. \\
\hline Search tool & Resolution. \\
\hline The most important results & $\begin{array}{l}\text { The existence of the dimensions of the quality of work life related to the } \\
\text { organizational and functional aspects in the first order gave satisfactory } \\
\text { solutions to the treatment method as well as the physical and moral work } \\
\text { environment that is the basis for providing all the conditions of occupational } \\
\text { health and safety and social relations. }\end{array}$ \\
\hline $\begin{array}{l}\text { The } \\
\text { recommendations }\end{array}$ & $\begin{array}{l}\text { The necessity for the municipality administration to pay attention to the } \\
\text { contributions of employees and encourage them, and take care of their welfare } \\
\text { to enhance their organizational commitment levels by building effective } \\
\text { systems of social, health and recreational care for them. }\end{array}$ \\
\hline
\end{tabular}




\section{THE SECOND AXIS : THE THEORETICAL SIDE}

First: electronic management

\section{1- The concept of electronic management}

Electronic management is considered as a term that has recently emerged, which is directly related to the management of the organization, and there were many opinions about defining its concept accurately due to its interference with many organizational and administrative matters of the organization, electronic management is one of the tools that directly relate to the organization and the tool that is managed through it The affairs of the organization electronically (Al-Hayek, 2016: 24). As for the concept of electronic management, which is one of the modern concepts in the science of management, it has been dealt with by many researchers according to different points of view, and Table (2) shows the concepts related to electronic management for some writers and researchers According to the time sequence:

Table (2) the concept of electronic management according to the opinion of some researchers

\begin{tabular}{|c|c|c|}
\hline & Researcher and year & Understood \\
\hline 1 & Rossel \& Matthias, 2012: 5 & $\begin{array}{l}\text { Use of modern technology that helps in good governance that obliges the } \\
\text { administration to provide remote services to citizens. }\end{array}$ \\
\hline 2 & (The Campaign, 2016: z) & $\begin{array}{l}\text { Employing information technology to enter and communicate to } \\
\text { increase the possibility of entering into electronic services in order to } \\
\text { benefit the citizens, business owners and employees of the organization. }\end{array}$ \\
\hline 3 & (Dahlez \& Labed, 2017: 7) & $\begin{array}{l}\text { Using information technology to provide electronic services directly to } \\
\text { citizens around the clock without being restricted by time restrictions. }\end{array}$ \\
\hline 4 & $\begin{array}{l}\text { (Al-Zuhairi \& Al-Quraishi, 2018: } \\
\text { 156) }\end{array}$ & $\begin{array}{l}\text { The use of modern communication technologies and their use in } \\
\text { controlling service delivery tasks at a level that contributes to the } \\
\text { efficient use of the organization's resources leading to providing the best } \\
\text { possible service to raise the efficiency of the organization. }\end{array}$ \\
\hline 5 & Hammdi et al., 2019: 594 & $\begin{array}{l}\text { Providing public services that are capable and efficient and that support } \\
\text { the expected benefits and benefits of the service according to a legal } \\
\text { framework and within the organization's contexts in a way that achieves } \\
\text { unconventional service. }\end{array}$ \\
\hline
\end{tabular}

Source: Preparing the two researchers based on the book above

Either researchers know electronic management is an integrated system that works according to modern and advanced technology that provides digital services via the internet and the electronic computer through qualified and trained people to provide these services with the aim of reducing red tape and delivering the service electronically without making time and effort.

\section{2- The importance of electronic management}

Electronic management is a human product and effort that seeks progress and progress to keep pace with scientific and modern developments aimed at facilitating human life, as electronic management with its tools represents an important means to improve services provided by organizations to citizens (Ari, 2008: 72), and the importance of electronic management can be summarized According to the opinion of (Al-Haiti, 2018: 73): 
1. Contributes to attracting and attracting external citizens, as the application of electronic systems reflects commitment, clarity and transparency, which reduces uncertainty compared to other organizations.

2. The process of monitoring and oversight of performance is facilitated by identifying the parties to internal control, forming specialized committees, and applying transparency and disclosure.

3. The organization helps to achieve sustainable growth and encourage productivity.

4. Organizations are encouraged to make optimal use of their resources efficiently.

The researchers believe that the importance of electronic management comes through its effective role in linking the organization to citizens through the means of information technology, and it enables citizens to communicate their complaints without mentioning the name or identity of the complainant.

\section{3-Dimensions of electronic management}

\section{Administrative requirements}

Electronic management to achieve the desired goal requires a good management that supports and supports development and change in accordance with modern administrative methods, and includes administrative requirements to develop strategies and plans for establishing, developing and organizing an administrative organization, as well as setting plans for administrative reform by attracting people with high skills and competencies (Al-Zaidi \& Khalil, 2015: 184), and the organization seeking to shift towards the electronic management method also entails attracting and appointing employees with electronic skills and sensitizing them to the importance of the transition towards the electronic management method (AbdelKarim, 2010: 24).

\section{Human requirements}

The human resource is one of the most prominent resources that lead societies to achieve progress and advancement in various areas of work, but the shortage of individuals qualified to adapt to the electronic work method has become something that organizations suffer, especially organizations working in developing countries (Alsalimi \& Alsiliti, 2008: 272 Therefore, organizations that intend to adopt the principles of electronic management and implement them physically must possess a human factor trained in the use of modern technologies, as investing in human capital is one of the most important investments that interest organizations in the current era, so investing in human capital is In order to ensure the success of the organization to establish an electronic business environment, this requires it to invest in a competent human resource and technical and technological expertise commensurate with the current developments taking place in the world through the information revolution.

\section{Technical requirements}

The technical requirements include the development of all technical aspects of the organization, such as software, technicians and the technical infrastructure of the organization, and the technical development process includes the analysis of all developed administrative works and their transformation into programs and applications in the computer, and it follows that the necessity of providing all the necessary hardware from computer networks, databases and information security devices In addition to the human resource (Abo Ashor \& Alnmri, 2013: 201), so an organization that wants to transform into an electronic method of management must overcome some obstacles first in order to be able to implement and adopt the electronic method in management, and these obstacles can be explained as follows: (Taib \& Alqosimi, 2013: 20)

A- The lack of an integrated infrastructure at the organization level, which impedes the process of implementing electronic management.

B - The difference in measurement and specifications of the devices used within the organization, which constitutes the difficulty of linking them.

\section{Financial requirements}

The shift towards adopting the electronic management method is considered one of the huge projects that need large amounts of money. For him (Alrubaie, 2017: 29), financial requirements play a decisive role in shifting 
towards the electronic management method, so the organization that wants to shift towards the electronic management method must provide the necessary support that is sufficient to carry out maintenance periodically and enables the organization to train dedicated cadres to conduct Maintenance is required continuously to maintain a high level of performance in providing service to citizens.

\section{Second: job performance}

\section{1- The concept of job performance}

Performance is a fundamental concept for governmental organizations and business organizations alike, and the concept of performance differs from one researcher to another according to the data and objectives of the research and according to the approach through which they look at performance (Davoudi \& Kaur, 2012: 69), as performance is the achievement, implementation and practice of anything that is ordered It is the result that can be observed directly and in a way by which it can be measured, evaluated and compared (Ahmad, 2019: 73), and the concept of performance differs from job performance, as performance includes the performance of the organization and workers in general, either job performance means the performance of employees in the organization and the level of that performance During the past century, researchers have paid more attention to conceptual issues related to job performance, as a concept through which they can deal, study and diagnose in an environment of continuous turmoil, and needs calling for reconsideration from time to time, as thinkers agreed to pay attention to the individual's performance in the organization and give it priority and care Necessary will make the organization reach its highest goals of survival, continuity and growth. Of course, most organizations seek to complete their work efficiently and effectively, in order to reach to achieve Targets previously planned and with minimal costs to reach those goals (Marjeh, 2019: 110).

The researchers and writers differed in setting a concept for specific and accurate performance, and this difference may be due to the large and varied fields through which the organization seeks to achieve good performance for workers through some incentives and the development of a clear and transparent vision that charts the future that the organization wants to achieve and other tools that help to To further improve the performance of workers, and many definitions have been received on job performance that the researcher will address in table (3) as follows:

Table (3) definitions related to job performance

\begin{tabular}{|l|l|l|}
\hline & Researcher and year & Understood \\
\hline 1 & (Al-Mashriqi, 2010: 146) & $\begin{array}{l}\text { The degree of achieving and completing the various tasks and responsibilities } \\
\text { that make up the job the employee occupies, and in what achieves the goals of the } \\
\text { organization, and this is done through improving performance in terms of quality, } \\
\text { by means of human resource management strategies represented in planning, } \\
\text { motivation, promotion, selection, appointment, and training, And continuous } \\
\text { development of employees }\end{array}$ \\
\hline 2 & (Fu \& Satish, 2014: 339) & $\begin{array}{l}\text { The outcome of the results and outputs achieved by the individual as a result of } \\
\text { his efforts in carrying out the duties and responsibilities assigned to him. }\end{array}$ \\
\hline 3 & (Ali and Moussa, 2015: 144) & $\begin{array}{l}\text { The work and tasks performed by the employee in the organization and the actual } \\
\text { results achieved in his field of work that contribute to achieving the goals of the } \\
\text { organization efficiently and effectively in accordance with the available } \\
\text { resources. }\end{array}$ \\
\hline 4 & (Abdel-Sayed, 2015: 76) & $\begin{array}{l}\text { The performance of the job holder who achieves high levels of job performance } \\
\text { in both the behavior and the output side in a manner consistent with and } \\
\text { achieving the goals of the organization }\end{array}$ \\
\hline
\end{tabular}




\begin{tabular}{|l|l|l|}
\hline 5 & (Wafik, 2016: 107) & $\begin{array}{l}\text { The employee performs the various activities and duties that constitute his work } \\
\text { in quantity and quality. }\end{array}$ \\
\hline 6 & (Atiyah, 2019: 51) & $\begin{array}{l}\text { The outcome of an individual's behavior in light of the procedures, techniques } \\
\text { and standards used in the organization and used in the work to achieve the } \\
\text { desired goals, as it is closely related to the work assigned to it. }\end{array}$ \\
\hline
\end{tabular}

Source: Prepared by the two researchers

\section{2-The importance of job performance}

Job performance is the force that represents any organization and reflects the final output of all the activities that it performs, whether at the individual level or the level of the organization as a whole, and it can be said in general that all organizations are performance part and parcel of it being a reflection of the capabilities and motivations of workers, as well as it also reflects The leaders' capabilities and capabilities that enable them to manage the organization with a high level of performance (Al Murad et al., 2013: 40).

The job performance has attracted the attention of many writers and researchers, as it is a basic indicator of economic and administrative progress, as well as being a targeted means to achieve any goal related to the organization, as it occupies an important position as the outcome of all activities at the individual and organizational level (Abdel Sayed, 2015: 78) .

The importance of job performance can be summarized as follows: (Mutashar, 2014: 106)

1. It is a measure of the ability of individuals to perform the tasks assigned to them at the present time and the tasks assigned to them in the future, in addition to job performance that helps management in the decisionmaking process.

2. Its association with the incentive system, which increases the interest of individuals in it.

3. It is related to the job stability of the workers, as the worker whose performance is low is always under the threat of being laid off.

4. Raising the level of performance is linked to improving work conditions and creating an atmosphere that helps workers to improve their performance.

5. The prominent role it plays in increasing productivity, thus enhancing the competitive position of the organization, as well as increasing its profits that contribute to the service of individuals and the organization.

\section{3-Dimensions of job performance}

\section{Job performance}

Job performance refers to job satisfaction in general, as well as a set of emotional feelings within workers towards work in the organization, and those feelings may be negative or positive depending on the conformity of his beliefs with what the work environment should be, so the higher the percentage of congruence, the more feelings about work Tend towards positivity, and vice versa, the lower the level of congruence, the more passive feelings and consequently the individual's level of job performance decreases (Saati and Khafaji, 2014: 244).

Job performance can be defined as the feelings that an individual possesses regarding his work. If the feelings are towards satisfaction, the individual will feel happy and thus this reflects on the job performance he provides, either if there is a lack of job performance and a desire to work, then this will lead to a decline in the level of Job performance due to dissatisfaction with work in the organization (Ahmed, 2019: 84).

\section{Productivity}

The meanings of productivity varied according to the opinion of researchers and writers, some of them adopt it in measuring work efficiency, while some adopt it as a measure of resource efficiency, and following the scientific school is one of the first advocates of productivity in the field of industry, and production capacity is defined as the ability to properly exploit available resources In order to achieve the goals of the organization, any productivity is measured by dividing the value of the outputs by the value of the inputs (AlAmri and Al-Ghalebi, 196: 2008). 
Productivity is a mainstay for implementing the organization's strategies and achieving its goals, as it occupies a great importance in the field of production as it represents the main goal that organizations focus on in order to continue to perform their tasks (Al-Lami and Abdul-Sahib, 2007: 4).

The productivity of workers is defined as "a set of processes, efforts made, and inputs that have been employed well in order to achieve a certain level of productivity by workers, and the level of productivity is evaluated by assessing the capabilities of workers to achieve the goals previously set" (Al-Ghouti, 2017: 37).

\section{Absence of workers}

Many organizations suffer from the phenomenon of absence from work in all countries of the world, and studies confirm that this phenomenon is constantly increasing in recent years, which led organizations to issue instructions to reduce them, and absence is defined as the non-attendance of the worker to work on time for him and participation in production according to what It is followed in the work program or schedule, or it is the case where the individual does not attend work for a whole day at a time when the work program indicates that he must be present at the specified time and place, either if the delay is less than a day, then it is considered a delay from work and not an absence and absence are two patterns: (Ahmed, 2019: 87)

a. Involuntary absence: It occurs as a result of reasons beyond the control of the worker or employee, for example, absence due to sudden illness or bad weather conditions.

B. Willful absence: It is intentional absence by the individual and is usually by prior planning by him or at the instigation of others as in the strike on the job and this type of dangerous indicators that warns of the existence of reasons worth studying to reduce this phenomenon.

Absence is defined as the inability of an individual or group of individuals to appear at the time specified for work for unforeseen reasons even though they are required to have known time limits to attend and leave (Abbas, 2011: 214).

\section{Creativity}

The current era is represented by the rapid changes and information revolution and the explosion of knowledge and technology, which resulted in many problems faced by contemporary organizations, as solving these problems requires the use of methods New creative and reject old methods and procedures, and this can only be done by finding creative people and providing appropriate means that help to find new methods and quick administrative solutions, hence creativity is one of the basic administrative components of organizations (Awad, 2013: 12).

Creativity, according to the researchers 'opinion, is a group of useful and new ideas that represent problem solving in administrative practices, operations, and structures that affect the administrative work and the operational process day after day.

\section{THE THIRD AXIS : THE PRACTICAL SIDE}

First: To test the correlation between the dimensions of electronic governance and the dimensions of job performance

The first axis is concerned with establishing the main and subsidiary research hypotheses that emerge from it, through the correlation coefficient, which studies the relationship between the main variables represented by (electronic management, job performance) and its subdimensions in the Municipality of Hilla, by measuring the direction and strength of the linear relationship between them, which appears with three relationships (When the correlation coefficient is equal to zero, the relationship between the variables is negated, and if it is more than zero to the positive one, it indicates the existence of a direct relationship, but if the correlation coefficient is less than zero, it indicates the inverse relationship between the variables), and the relationship can be counted weak if the coefficient value The correlation is less than $(0.30)$, and its average count is when it appears between (0.30-0.60), but when its value is more than (0.60), the relationship between the variables is strong.

a. The correlation between the electronic administration and the job performance in the Municipality of Hilla, in general, and at the level of dimensions 
The first main hypothesis started from the expectation (the presence of a statistically significant correlation relationship statistically between electronic administration and job performance in the Municipality of Hilla in its dimensions), and table (4) showed positive positive correlations between electronic administration and job performance in the Municipality of Hilla in general and at the dimension level, As the results were as follows:

1- Table (4) showed the administrative requirements as an independent dimension (2) a positive positive moral relationship model out of (5) with the total and dimensions of the job performance, i.e. $(40 \%)$ of the relationships, as it achieved an unrelated (0.126) relationship with Total job performance, a direct correlation relationship with the approved productivity dimension $(0.259 * *)$ and an inverse moral correlation relationship with the absence of workers $(0.211-* *)$, and finally, no correlation relationship was achieved with the dimension of job performance and after creativity, as the results indicate that a society The research uses the administrative requirements in (productivity and the absence of workers) with the exception of after job performance and creativity and at the overall level (job performance), and the increase in mutual influence between them will lead to a change in the same direction, and this result leads to the rejection of the first sub hypothesis of the first main hypothesis (the existence of a relationship Significant correlation between administrative requirements and job performance in Hilla Municipality directorate with its dimensions.

2- Table (4) showed human requirements as an independent dimension (4) model of positive positive moral relationship out of (5) with total and dimensions of job performance, i.e. (80\%) of relationships, as it achieved a correlation relationship $(0.320 * *)$ of moral With total job performance, a direct correlation relationship with the approved dimension, job performance $(0.291 * *)$, and a significant correlative correlation relationship with the productivity dimension $(0.404 * *)$ and also achieved a correlation relationship with the dimension of creativity $(0.249 *)$, and finally did not achieve any correlation relationship with After the absence of workers (0.124-), as the results indicate that the research community uses human requirements for job performance at the macro level and with dimensions except for after the absence of workers, and that the increase in the mutual influence among them will lead to a change in the same direction, and this result carries the relationship Clear and strong participation of employees and beneficiaries from expressing opinions, proposals and possible solutions to prevailing problems and situations that lead to raising the level of job performance, leading to achieving goalsThe Directorate effectively and efficiently towards further growth and continuity, from that we conclude that the Directorate allows participation of all parties in decision-making and drawing policies, which is reflected positively in achieving job performance, and this result leads to accepting the second sub-hypothesis from the first main hypothesis (and there is a correlation with significant significance) Between participation and job performance in the Municipality of Hilla, with its dimensions).

3- Table (4) showed the technical requirements as an independent dimension (5) model of positive positive moral relationship out of (5) with total and dimensions of job performance, i.e. (100\%) of the relationships, as it achieved a correlation relationship $(0.426 * *)$ of moral With total job performance, a direct correlation relationship with the approved dimension, job performance $(0.477 * *)$, and a significant correlative correlation relationship with the productivity dimension $(0.531 * *)$ and also achieved a correlation relationship with the dimension of creativity $(0.353 * *)$, and finally achieved an inverse moral correlation relationship With the absence of the employees (0.269-), as the results indicate that the directors in the Hilla Municipality directorate deal fairly at one distance from everyone without preference for one party over another and to ensure satisfaction among the workers in it, it is expected that a better performance level will accompany this organization Accordingly, it can be said that the Hilla Municipality directorate is working to establish human requirements by adopting this principle in nominating training courses and administrative positions and resolving many issues, as it works to build good relations characterized by justice between the beneficiaries inside and outside in an effort to raise the efficiency of performance, and this result Lead to accept the branch hypothesis The third of the first main hypothesis (there is a significant correlation between 
justice and job performance in Al Hilla Municipality directorate with its dimensions).

3- Table (4) showed the financial requirements as an independent dimension (5) model of positive positive moral relationship out of (5) with the total and dimensions of job performance, i.e. (100\%) of the relationships, as it achieved a correlation relationship $\left(0.260^{* *}\right)$ of moral With the total job performance, a direct correlation relationship with the approved dimension, job performance $(0.364 * *)$ and a significant correlative correlation relationship with the productivity dimension $(0.373 * *)$ and also achieved a correlation relationship with the dimension of creativity $(0.269 * *)$, and finally achieved an inverse moral correlation relationship With the absence of the employees (0.332-), as the results indicate a high level of job performance by providing financial requirements that work to organize the correct social relations between individuals forcibly or voluntarily, and this result leads to accepting the fourth sub-hypothesis from the first main hypothesis (having a correlation relationship) Significant between financial requirements and job performance in the Municipality of Hilla, with its dimensions.

Table (4) Relationships of the dimensions of electronic administration with the job performance of the Municipality of Hilla, with its dimensions

\begin{tabular}{|c|c|c|c|c|c|c|}
\hline $\begin{array}{l}\text { Total electronic } \\
\text { administration }\end{array}$ & $\begin{array}{l}\text { Financial } \\
\text { requirements }\end{array}$ & $\begin{array}{l}\text { Technical } \\
\text { requirements }\end{array}$ & $\begin{array}{l}\text { Human } \\
\text { requirements }\end{array}$ & $\begin{array}{l}\text { Administrative } \\
\text { requirements }\end{array}$ & $\begin{array}{l}\text { Dimensions } \\
\text { governance }\end{array}$ & of eleetronic \\
\hline$* * 0.446$ & $* * 0.364$ & $* * 0.477$ & $* * 0.291$ & 0.166 & $\begin{array}{l}\text { Pearson } \\
\text { coefficient }\end{array}$ & \multirow[t]{2}{*}{ Job Satisfaction } \\
\hline 0.000 & 0.000 & 0.000 & 0.003 & 0.096 & Sig & \\
\hline$* * 0.543$ & $* * 0.373$ & $* * 0.531$ & $* * 0.404$ & $* * 0.259$ & $\begin{array}{l}\text { Pearson } \\
\text { coefficient }\end{array}$ & \multirow[t]{2}{*}{ Productivity } \\
\hline 0.000 & 0.000 & 0.000 & 0.000 & 0.009 & Sig & \\
\hline$* *-0.309$ & $-* * 0.332$ & $* *-0.269$ & -0.124 & $* *-0.211$ & $\begin{array}{l}\text { Pearson } \\
\text { coefficient }\end{array}$ & \multirow{2}{*}{$\begin{array}{l}\text { Absence } \\
\text { workers }\end{array}$} \\
\hline 0.002 & 0.001 & 0.006 & 0.215 & 0.033 & Sig & \\
\hline$* * 0.345$ & $* * 0.269$ & $* * 0.353$ & *0.249 & 0.130 & $\begin{array}{l}\text { Pearson } \\
\text { coefficient }\end{array}$ & \multirow[t]{2}{*}{ creativity } \\
\hline 0.000 & 0.006 & 0.000 & 0.012 & 0.194 & Sig & \\
\hline$* * 0.397$ & $* * 0.260$ & $* * 0.426$ & $* * \mathbf{0 . 3 2 0}$ & 0.126 & $\begin{array}{l}\text { Pearson } \\
\text { coefficient }\end{array}$ & \multirow[t]{2}{*}{ Functionality } \\
\hline 0.00 & 0.008 & 0.000 & 0.001 & 0.207 & Sig & \\
\hline
\end{tabular}

**correlation is significant at the level $0.01(2$ tailed)

*correlation is significant at the level $0.05(2$ tailed)

On this basis, the difference in the strength of the relationship between the dimensions of electronic management and job performance is clear according to what has been presented, and therefore these dimensions can be arranged in terms of the strength of their relationship with the job performance variable according to the values of simple linear correlation coefficients starting with the highest correlation coefficient down to its lowest value as shown in: 


\section{Functionality}

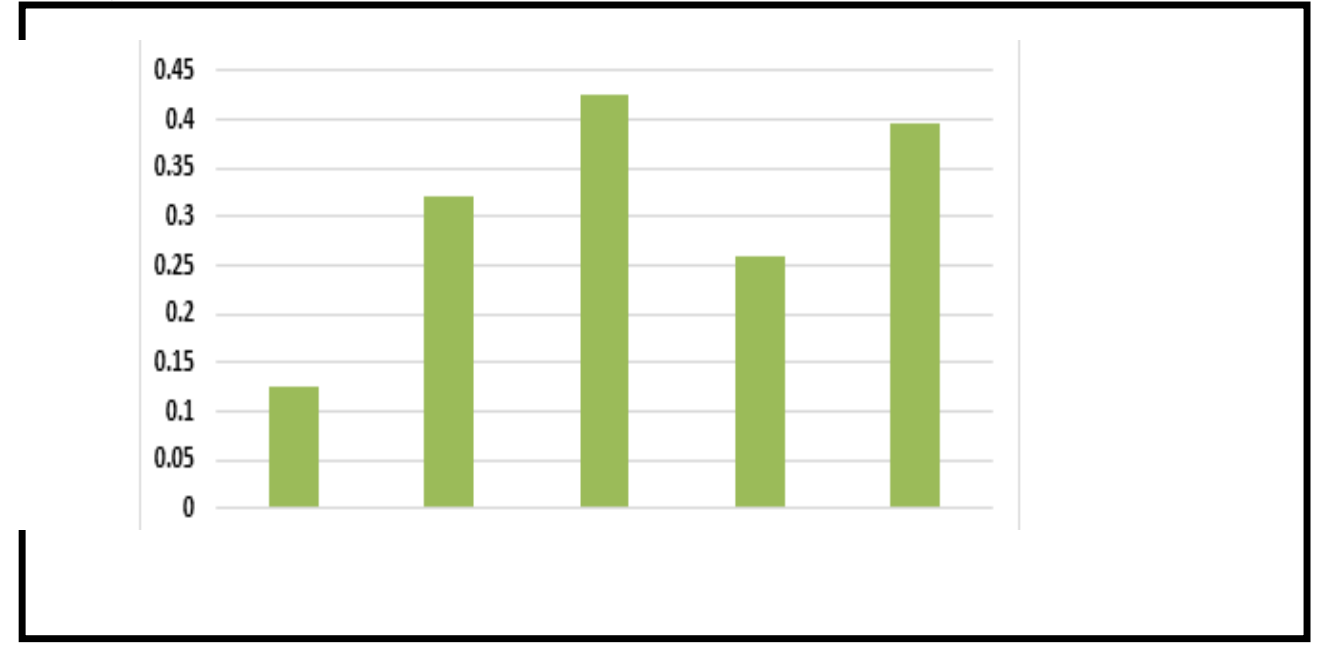

Electonic managementFinancial requirementsTechnical requirementsHuman requirementsAdministrative requirements

Figure (2) coefficients of the dimensions of electronic administration with job performance

Figure (2) shows the achievement of the technical requirements after the first rank in terms of the strength of the correlation relationship with job performance, as the strength of the relationship between them reached (426). This indicates the importance of providing technical requirements in the Municipality of Hilla to reach the job performance, and came after the human requirements at the second rank As the strength of the relationship with the job performance reached (320), which indicates that the Municipality of Hilla seeks to provide human requirements that contribute to the formulation of policies as well as to provide opportunities for all parties to present their proposals and views on the nature of the service provided, which is reflected positively in enhancing the job performance After the financial requirements, he achieved the third rank, as the strength of the relationship with the job performance reached (260), which indicates the awareness of the presidency of the research council of the necessity of providing material support and its significant role in organizing relationships inside and outside the directorate, which leads to achieving job performance, followed by Fourth rank after the administrative requirements in terms of the strength of the relationship of association with job performance, as the strength of the relationship between them (126). This indicates that the Hilla Municipality directorate is working to provide the administrative requirements It is necessary to adopt the electronic management method.

The final result reached and shown in Table (4) regarding the results of the test of the electronic management relationship with the job performance at the aggregate level of the two variables with the dimensions of each, that the linear relationship between them is a strong positive relationship in its direct direction with the function of the positive linear correlation coefficient (397). (Between them and the statistically significant level with a complete level of significance $(\mathrm{P}=0.000)$ and confirming the validity of the first main hypothesis of the research in terms of the expected positive relationship between the two explanatory variables (electronic management) and the response variable (job performance) as if in the case of increased interest in applying the dimensions of electronic management or its mechanisms by a unit One quantity, this is not reflected in the increase in the level of job performance by the value of the gradient slope or the beta coefficient of value (391.)

Second: testing and analyzing impact hypotheses

The current second axis seeks to verify the hypotheses of influence among research variables, using statistical methods represented by (Simple Regression Analysis), 
simple linear regression analysis, for influence relationships between the main research variables, the effect (electronic management and its dimensions) as an independent variable in the dependent variable (job performance) according to The following regression equation:

$\mathbf{Y}=\mathbf{a}+\mathbf{B}(\mathbf{x i})$

a. The effect of electronic administration on job performance in the Municipality of Hilla
The second main hypothesis was launched from the expectation (the presence of a significant effect of electronic management on the job performance in the Municipality of Hilla), and for the purpose of verifying the validity of the hypothesis or not, simple regression models were implemented, according to the subhypotheses that emanated from the second main hypothesis.

Table (5) the effect of electronic management and its dimensions on job performance

\begin{tabular}{|c|c|c|c|c|c|c|}
\hline \multirow{2}{*}{$\begin{array}{l}\text { FCalculated } \\
\text { the model }\end{array}$} & \multirow[b]{2}{*}{ Sig } & \multicolumn{4}{|c|}{ Approved Variable (Functional Performance) } & \multirow{2}{*}{$\begin{array}{l}\text { Dimensions } \\
\text { electronic } \\
\text { management }\end{array}$} \\
\hline & & $\mathbf{a}$ & $\mathbf{b}$ & $R^{2}$ & $\boldsymbol{\beta}$ & \\
\hline 1.614 & 0.207 & 3.163 & 0.097 & 0.016 & 0.126 & $\begin{array}{l}\text { Administrative } \\
\text { requirements }\end{array}$ \\
\hline 11.407 & 0.001 & 2.692 & 0.223 & 0.102 & 0.320 & Human requirements \\
\hline 22.149 & 0.000 & 2.534 & 0.279 & 0.181 & 0.426 & $\begin{array}{l}\text { Technical } \\
\text { requirements }\end{array}$ \\
\hline 7.239 & 0.008 & 2.727 & 0.209 & 0.067 & 0.260 & $\begin{array}{l}\text { Financial } \\
\text { requirements }\end{array}$ \\
\hline 18.671 & 0.000 & 2.045 & 0.391 & 0.157 & 0.397 & $\begin{array}{l}\text { electronic } \\
\text { management }\end{array}$ \\
\hline
\end{tabular}

Sig=0.01 $F=6.33 \mathrm{df}=101$

1- The impact of administrative requirements on job performance

Table (5) showed an effect model for the independent dimension, the administrative requirements in the Municipality of Hilla in the approved variable (job performance), under a significant level ( $\operatorname{sig}=0.207$ ) which is greater than the value of the significance $(0.01)$ and in terms of the calculated value of (F) (1.614) Less than the tabular value $(F)(6.33)$, as the value of the determination factor $\left(\mathrm{R}^{2}=0.016\right)$, and indicates that the independent dimension administrative requirements explain what its value $(2 \%)$ of job performance, and the value of $(\beta=0.126)$, that is, The change for one unit in the administrative requirements will lead to a change in job performance by $(12.6 \%)$, as this result provides sufficient support to reject the first sub-hypothesis of the second main hypothesis (the presence of a statistically significant effect of administrative requirements in the job performance in the Municipality of Hilla). It is an acceptable effect, and in a proxy regression model:
Job Performance $(Y)=3.163+0.097$ (Administrative requirements)

2-The effect of human requirements on job performance

The determination coefficient for testing the impact of human requirements on job performance reached (102) and with full statistical significance $(\mathrm{P}=0.001)$ also presented in Table (5), expressing the impact force left by the freedom to express opinions and personal expression by providing the necessary human cadres to work according to a method Electronic management in the Municipality of Hilla, which plays a role in taking decisions and drawing the necessary policies to adopt the method of electronic management and creating cases of constructive interaction between all parties concerned that lead to raising the level of job performance in the Directorate of Hilla Municipality as the organization subject to research, and this in turn means correctness The second sub-hypothesis at the level of influence 
hypotheses that emerged from the second main hypothesis to research regarding the expected impact of electronic management through the human requirements dimension in job performance, and for the complement factor determining (0.898) it certainly represents a percentage of interpretation related to other factors not included in the special test model With this hypothesis.

It is an acceptable effect, and in a proxy regression model:

Job performance $(\mathrm{Y})=2.692+0.223$ (human requirements)

3- The impact of technical requirements on job performance: The results of the expected impact analysis of the technical requirements dimension from among the rest of the dimensions of the explanatory or independent variable, represented by the electronic management in the dependent variable or response variable embodied in the job performance, as shown in Table (14) itself yielded the determination of the highest parameter It has (. 181), among other tests, with full statistical significance $(P=0,000)$, indicating that a high percentage of variation in the level of job performance in the Hilla Municipality directorate is explained by the administration providing the technical requirements for the cadres in the directorate, which facilitate the process of adopting the electronic management method so that There is almost a dominant culture at the level of the directorate that guarantees the satisfaction of all of its employees, and thus improves the quality of its performance, and this, in turn, also reflects the validity of the third sub-hypothesis from among the other hypotheses of influence as well.

It is an acceptable effect, and in a proxy regression model:

\section{Job Performance $(Y)=2.534+0.279$ (Technical} requirements)

4- The impact of financial requirements on job performance

Table (5) showed an effect model for the independent dimension: the financial requirements in the Municipality of Hilla in the approved variable (job performance), under a significant level $(\mathrm{sig}=0.008)$ which is less than the value of significance (0.01) and in terms of the calculated value of (F) (7.239) which is greater From the tabular value of (F) (6.33), as the value of the determination factor $\left(\mathrm{R}^{2}=0.067\right)$, and indicates that the independent dimension of financial requirements explains what is its value $(7 \%)$ of job performance, and the value of $(\beta=0.260)$, that is, the change For one unit in the financial requirements will lead to a change in job performance by $(26 \%)$, as this result provides sufficient support to accept the fourth sub-hypothesis from the second main hypothesis (the presence of a statistically significant effect of financial requirements on job performance in the municipality of Hilla), which is An acceptable effect, with a regression model of agency:

Job performance $(\mathrm{Y})=2.727+0.209$ (financial requirements)

5 Table (14) showed an effect model for the independent variable of electronic management in the Municipality of Hilla in the approved variable (job performance), under a significant level $(\mathrm{sig}=0.000)$ which is less than the value of significance (0.01) and in terms of the calculated value of $(\mathrm{F})$ (18.671) which is Above the tabular value (F) (6.33), as the value of the determination coefficient $\left(\mathrm{R}^{2}=0.157\right)$, and indicates that the independent variable of electronic administration explains what is its value (15.7\%) of job performance, and the value of $(\beta=0.397)$, that is, The change for one unit in electronic management will lead to a change in job performance by (39.7\%), as this result provides sufficient support to accept the second main hypothesis (the presence of a statistically significant effect of electronic management on job performance in the Municipality of Hilla), which is an acceptable effect In an agency regression model:

Job Performance $(\mathrm{Y})=\mathbf{2 . 0 4 5}+\mathbf{0 . 3 9 1}$ (Electronic Management) 


\section{FOURTH AXIS : CONCLUSIONS AND RECOMMENDATIONS}

First: Conclusions

1- The administration has a tendency to adopt serious and non-stereotypical ideas regarding the topics of employing computer technologies and programs to facilitate work for the employee first and the citizen second.

2- The Hilla municipality administration seeks to develop a specialized cadre to train employees on electronic programs, as well as to create a unified database to facilitate the process of referring to files and data when needed.

3-The Hilla Municipality directorate is keen on preparing specialized technical human cadres that are related to the information structure, by introducing employees to specialized training courses in this field to raise their competence and provide them with the necessary expertise to deal with these programs.

4- The Directorate possesses advanced technological devices and equipment, as the best devices are provided from computers and specialized programs that are employed in favor of the application of electronic management.

5- The directorate establishes within its financial accounts a financial balance for the purchase of all equipment and supplies related to the implementation of the e-management application. In addition to the directorate having the necessary allocations to hold training courses for employees.

6- Although the Directorate has the financial allocations to create all the requirements for the application of electronic management, it suffers at times from a lack of liquidity as a result of the general conditions in the country.

9- The workers in the council feel a kind of job performance for many reasons:

a. Accept their proposals and complaints if presented
B. The administration continuously strives to fulfill the employees desires in a way that increases their loyalty to the Bureau.

10- There is a disparity in the employee getting additional wages and benefits, and therefore the effect on the level of productivity at work.

11- The absence of employees arises as a result of disputes with colleagues, as well as health reasons and social and family obligations.

Second: Recommendations

1- The necessity for the administration to develop a specialized staff in this field to train employees on the programs that are employed in the work

2- The administration should create a unified database for easy reference to files or work-related information.

3- The directorate must allocate funds for the issue of training and development on the use of these technologies and create a working group capable of dealing with emerging problems that do not appear until the time of work on the programs.

4- The necessity of providing and preparing the electronic forms and documents necessary for the implementation of the electronic government by the directorate.

5- The necessity of overcoming the weak capabilities of the employees in matters of speed of processing or migrating data, as the electronic communication technology used in the directorate suffers from problems in some cases, thus this matter is reflected on the level of service provided by the directorate with other agencies that deal with it.

6- The necessity of providing financial allocations to create all requirements for the application of electronic management in a way that is reflected at the level of progress in work on the subject of application or implementation of electronic management or in terms of implementing training courses related to electronic management.

7- The necessity of distributing the tasks clearly to the employees in a way that enables them to provide a good 
level of work on the subject of implementing or implementing electronic management or in terms of implementing training courses related to electronic management.

8- The Hilla Municipality directorate tries to resolve disputes that arise between employees and control them quickly, which arise as a result of employees feeling the differences in wages and incentives.
9- The necessity for the administration to pay attention to the requirements of the employees and for the wages and benefits received by the employees to be compatible with the nature of the work assigned to them.

10- The necessity for the directorate to adopt creative ideas and support them to activate the wheel of creativity by the rest of the employees until the stage of complete completion.

\section{SOURCES}

\section{First: books}

1. Abbas, Anas Abdul Basit, (2011), "Human Resources Management", first edition, Dar Al Masirah for Publishing and Distribution, Amman - Jordan.

2. Al-Amri, Saleh, and Al-Ghalabi Taher, (2008), "Administration and Business", second edition, Wael House for Publishing and Distribution, Amman - Jordan.

3. Ari-VeikkoAnttiroiko. (2008). Electronic Government: Concepts, Methodologies, Tools, and Applications, Information Science reference, Hershey, New York.

\section{Second: Master thesis}

1. Ahmad, Muhammad Thanoon, (2019), "Reflection of disciplinary procedures for employees on job performance field research in the Directorate of Ash Municipality", unpublished higher diploma research, College of Administration and Economics - University of Baghdad.

2. Abdel-Sayed, Ghazi Abdel-Zaid Karim, (2015), "The Role of High Performance Work Systems in Outstanding Job Performance Through the Intermediate Role of Human Resource Flexibility - An Analytical Study of Sample Views of Municipal Department Staff in Holy Karbala”, Unpublished Master Thesis, College of Administration and Economics, University of Karbala.

3. Al-Ghouti, Mahmoud Ahmed Salem, (2017), "The Role of Strategic Planning in Raising Productive Efficiency among Workers in Higher Education Institutions in Gaza Governorate", published Master Thesis, College of Education - Islamic University, Gaza.

4. Mutashar, Atheer Muhammad, (2014), "The strategic vision and its impact on nursing performance - field research at Ibn Al-Nafees Hospital," unpublished Master Thesis, College of Administration and Economics - University of Baghdad.

\section{Third: The published research}

1. Abdel-Karim, Ashour, (2010), "The role of electronic administration in rationalizing public service in the United States and Algeria, published message, Faculty of Law and Political Science - University of Mentouri - Constantine.

2. Al-Haiti, SaeedHamad, (2018), "The relationship between e-governance and integration strategy and its reflection on organizational excellence - field study in the Department of Research and Development / Ministry of Higher Education and Scientific Research," unpublished thesis, College of Administration and Economics - University of Baghdad.

3. Al-Hayek, Noha Ahmed, (2016), "The Impact of Applying Governance to Improving Performance in Governmental Institutions - Case Study of the General Directorate of Syrian Customs", published Master Thesis, Syrian Virtual University.

4. Al Murad, NawalYounis, Muhammad, Athamar Abdul Razzaq, Hadi, Anwar, (2013), "The Impact of Organizational Value on Job Performance / An Applied Study of the Views of a Sample of Central Administration Managers in a Number of Governmental Hospitals in Nineveh," published research, Tikrit Magazine Administrative and Economic Sciences, Volume 9, No. 29. 
5. Al-Saati, Afaf Hassan Hadi and Al-Khafaji, Yasser Adel Mahmoud, (2014), "Organizational Culture and its Impact on Promoting Career Creativity - Research in the Modern Painting Industries Company," published research, Journal of Administrative and Economic Sciences, Volume 20, No. 76.

6. Attia, Al-Arabi, (2019), "The effect of using information technology on the job performance of workers in local government agencies - a field study at the University of Ouargla - Algeria," research published in the researcher's journal, No. 10.

7. Ali, Kholoud, Moussa, Nada Badr, (2014), "Securing the Protection of E-Governance Websites for Companies in Basra Governorate - An Exploratory Study,” published research, Journal of Basra Studies, Volume 18, ninth year.

8. Al-Lami, GhassanDawood, and Abdul-Saheb, Haider Muhammad, (2007), "An Analytical Study of the Reality of Production Capacity Planning Work in Karbala Cement Factory", published research, Journal of Administrative Studies, Volume 1, No. 3.

9. Al Hamila, TahseenAssi, (2016), "The Role of Organizational Citizenship in the Application of E-Governance," published research, Al-Kout Journal of Economic and Administrative Sciences, No. 23.

10. Al-Aqabi, Nasser OwaidAttia, and Al-Rubaie, Kholoud Hadi Abboud, (2018), "Analysis of the requirements of electronic management and its role in improving the job performance of human resources - applied research in general Iraqi insurance companies, "Published research, Journal of Accounting and Financial Studies, volume 13 Issue 45.

11. 7. Al-Zaidi, Nazem Jawad Abdul, Khalil, Zainab Mustafa, (2015), "Rehabilitation of human resources for the application of electronic management - a case study in the Ministry of Science and Technology," published research, Journal of Economic and Administrative Sciences, Volume 21, No. 86.

12. Al-Zuhairi, TalalNazimKhudair, and Al-Quraishi, Fadel Abdul Ali Khurmit (2018), "Applying the principles of egovernance based on human resource capabilities to raise the level of performance in information institutions." Published research, Lac of Philosophy, Linguistics and Social Sciences, No. 29.

13. Dahlez, Khaled, and Lebed, Khaled, (2017), "The Elements of Success for E-Government Application in Palestine An Exploratory Study," published research, An-Najah University Journal for Research and Humanities, Volume 31, No. 7.

14. Hammadi, Salih Mahdi, Ibrahim, Ammar Ghazi, and Abdul Karim, Nizar Maan, (2019), "The Impact of Electronic Governance on Auditing Quality - Applied Research in Economic Organizations," published research, Journal of the College of Economic and Administrative Sciences, Volume 25, No. 111.

15. Rossel, pierre\& Matthias, (2012), "Finger, conceptualizing E-Governance management", vol.12, No 23. 